4. Schuff N, Amend D, Ezekiel F, et al. Changes of hippocampal $N$-acetylaspartate and volume in Alzheimer's disease. A proton MR spectroscopic imaging and MRI study. Neurology 1997;49: 1513-1521.

5. Pfefferbaum A, Adalsteinsson E, Spielman D, Sullivan EV, Lim KO. In vivo brain concentrations of $N$-acetyl compounds, creatine, and choline in Alzheimer disease. Arch Gen Psychiatry 1999;56:185-192.
6. Adalsteinsson E, Sullivan EV, Kleinhans N, Spielman DM, Pfefferbaum A. Longitudinal decline of the neuronal marker $N$-acetyl aspartate in Alzheimer's disease. Lancet 2000;355: 1696-1697.

7. Rose SE, de Zubicaray GI, Wang D, et al. A ${ }^{1} \mathrm{H}$ MRS study of probable Alzheimer's disease and normal aging: implications for longitudinal monitoring of dementia progression. Magn Reson Imaging 1999;17:291-299.

\title{
Neuro/mages
}
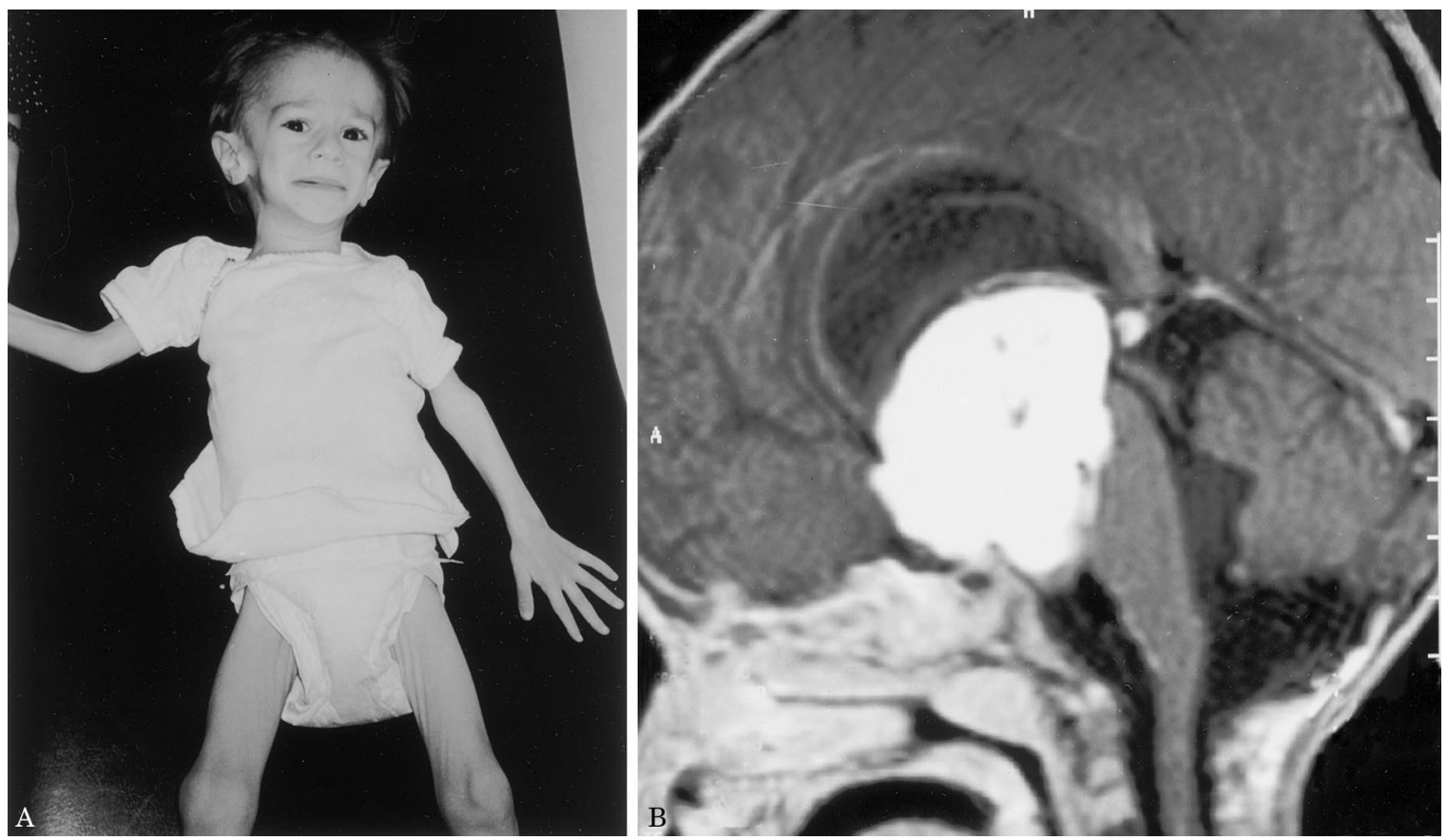

Figure. (A) The index patient. Note the severe emaciation of the whole body and the characteristic "pseudohydrocephalic" appearance. (B) MRI of the brain. T1-weighted sagittal images (repetition timelecho time: 570/15) after gadolinium enhancement demonstrate the presence of a large tumor involving the hypothalamic region, distorting the chiasm and brainstem, and extending into the third ventricle. Neuropathologically, the tumor proved to be a hypothalamic astrocytoma with pilomyxoid features.

\section{Russell's diencephalic syndrome}

Dimitrios I. Zafeiriou, MD, PhD, Dimitrios Koliouskas, $M D, P h D$, Euthymia Vargiami, $M D$, and Nikolaos Gombakis, $M D, P h D$, Thessaloniki, Greece

A 21-month-old boy was initially admitted to our hospital because of failure to thrive, which began at the age of 6 months. Physical examination revealed emaciation (weight $<$ third percentile), normal body length, normal head circumference with a characteristic "pseudohydrocephalic" face (figure, A), as well as a mild pyramidal tract dysfunction, in an otherwise alert child with limited speech but with appropriate cognitive abilities for his age. An MRI of the brain was performed, which revealed a large, partly solid, partly cystic mass in the suprasellar region, distorting the chiasm and brainstem and extending well up through the hypothalamus and into the third ventricle (see the figure, B); the above-mentioned tumor neuropathologically proved to be an astrocytoma with pilomyxoid features.
Russell's diencephalic syndrome, which is manifested by progressive emaciation and failure to thrive in an apparently alert infant, usually is due to a low-grade hypothalamic astrocytoma. ${ }^{1,2}$ The normal head circumference despite the severe loss of adipose tissue of the face sometimes gives the impression of a characteristic pseudohydrocephalic appearance.

\section{Acknowledgment}

The authors thank Prof. Peter Landos (Department of Neuropathology, King's College Hospital, London, UK) for the neuropathologic diagnosis.

1. Ertem D, Acar Y, Alper G, Kotiloglu E, Pehlivanoglu E. An uncommon and often overlooked cause of failure to thrive: diencephalic syndrome. J Pediatr Gastroenterol Nutr 2000;30:453-457.

2. Poussaint TY, Barnes PD, Nichols K, et al. Diencephalic syndrome: clinical features and imaging findings. AJNR Am J Neuroradiol 1997;18: 1499-505. 


\title{
Neurology
}

\author{
Russell's diencephalic syndrome \\ Dimitrios I. Zafeiriou, Dimitrios Koliouskas, Euthymia Vargiami, et al. \\ Neurology 2001;57;932 \\ DOI 10.1212/WNL.57.5.932
}

This information is current as of September 11, 2001

\section{Updated Information \& Services}

References

Subspecialty Collections

Permissions \& Licensing

Reprints including high resolution figures, can be found at: http://n.neurology.org/content/57/5/932.full

This article cites 2 articles, 0 of which you can access for free at: http://n.neurology.org/content/57/5/932.full\#ref-list-1

This article, along with others on similar topics, appears in the following collection(s):

All Imaging

http://n.neurology.org/cgi/collection/all_imaging

Information about reproducing this article in parts (figures,tables) or in its entirety can be found online at:

http://www.neurology.org/about/about_the_journal\#permissions

Information about ordering reprints can be found online:

http://n.neurology.org/subscribers/advertise

Neurology ${ }^{\circledR}$ is the official journal of the American Academy of Neurology. Published continuously since 1951, it is now a weekly with 48 issues per year. Copyright . All rights reserved. Print ISSN: 0028-3878.

Online ISSN: 1526-632X.

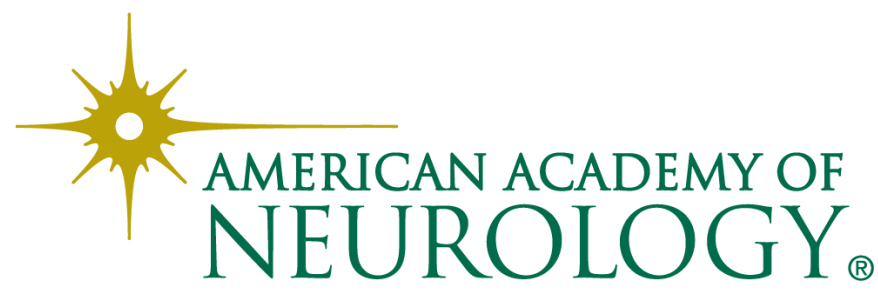

